\title{
Design of Air Ventilation System for Cargo Hold Vessels using Solar Desiccant
}

\author{
Alam Baheramsyah ${ }^{1}$, Taufik Fajar Nugroho ${ }^{2}$, Prasetyo Adi Wibowo ${ }^{3}$
}

\begin{abstract}
- one of the facilities and infrastructure of the vessel is the ventilation system in the cargo hold to maintain the quality. One attempt to avoid high moisture ratios is to provide a dry air supply by using desiccants. The purpose of this thesis is to design the system of air ventilation with solar desiccant by analysis the calculation with decrease air humidity ratio after passing desiccant rotor as well as fulfillment needs of heater and cooling system using heat of exhaust gas and seawater as well as fulfillment of electricity need using solar energy. From the result of analysis obtain to provide air supply in the cargo hold of $437.5 \mathrm{~m}^{3}$ / hour, the specification of rotor desiccant has a diameter of $550 \mathrm{~mm}$ with thickness $200 \mathrm{~mm}$ to decrease ratio of outside air humidity equal to $83.1 \%$ become $46.5 \%$. Dehumidification air temperature of $47.7^{\circ} \mathrm{C}$ will be lowered to $35^{\circ} \mathrm{C}$ by using the sea water cooling media. As for the reactivation air heater requirement of $24.292 \mathrm{~kW}$ would be to fulfilled by utilizing the exhaust power of $498.12 \mathrm{~kW}$. And for the electric power needs of the syetm is $34,488 \mathrm{wp}$ will be supplied from the total solar module is 33 units with 345 wp per-capacity.
\end{abstract}

Keywords: air ventilation, cargo hold, pelayaran rakyat vessel, solar desiccant.

\section{INTRODUCTION}

$\mathrm{V}$ essels used as a logistics transport from a small port, to a port hub-port, the above function is a function of the people's voyage to ensure the availability of national logistics system to inland areas. The role of the people's sail in "Sea Highway" also plays an important role in safeguarding the stability and availability of logistics, especially in areas that are difficult to reach by land transport rice, cement, fertilizer, food are some of the freight carried by Pelayaran Rakyat vessels. In addition, Pelayaran Rakyat vessels are also used for river transport such as in Kalimantan, and Sumatra. One of the facilities and infrastructures of the Pelayaran Rakyat vessels is the air ventilation system in cargo hold which is useful to keep the cargo quality in good condition.

Natural air ventilation systems for cargo hold Pelayaran Rakyat vessels are considered less effective for some items such as rice, flour or other foods.

Alam Baheramsyah, Department of Marine Engineering, Institut Teknologi Sepuluh Nopember, Campus ITS Sukolilo-Surabaya 60111, Indonesia, Email : alam@its.ac.id

Taufik Fajar Nugroho, Department of Marine Engineering, Institut Teknologi Sepuluh Nopember, Campus ITS Sukolilo-Surabaya 60111, Indonesia, Email : taufikfajar@its.ac.id

Prasetyo Adi Wibowo, Department of Marine Engineering, Institut Teknologi Sepuluh Nopember, Campus ITS Sukolilo-Surabaya 60111, Indonesia, Email : Prasetyo.Wibowo@mhs.ne.its.ac.id
This is because the system is heavily dependent on the surrounding air condition especially for its temperature and humidity [1-5], so that when the outside air condition has high temperature and humidity which is too high can cause the quality of the cargo brought mainly to the unsuitable quality of the existing standard because of excess moisture in the cargo hold [2-11].

The region of Indonesia is in tropical climate with a range of temperatures in waters of $27^{\circ} \mathrm{C}$ with a humidity level of $80 \%$, while the normal temperature recommended for the charge is $43^{\circ} \mathrm{C}$ with a relative humidity value of $65 \%$. With the difference in environmental conditions, the charge will be affected by micro-climate elements, especially air humidity [12-18].

In addition to the use of renewable energy for the fulfillment of the heating system needs of the dehumidification system will use exhaust gas from the engine and the fulfillment of the electrical power needs used for the fulfillment of electrical power from the rotary desiccants system using solar thermal energy which is then converted through the system from photovoltaic [13].

Air ventilation system is the process of providing fresh air into the room or out of the dirty air of a room naturally and mechanically. The air venting system on the vessel has the function of maintaining chemical composition and humidity or keeping it as requirment in the vessel's room, by regulating the flow of air into out of the vessel in order to perform the process of replacing the already dirty air with fresh air and Adjust the temperature, pressure and chemical composition of the air inside the vessel [2]. With the occurrence of the process will be able to fulfill the purpose of ventilation in the vessel.

Desiccant is one of the hygroscopic substances that can absorb moisture by put away water inside the capillary or surface of an item while maintaining the presence of water 
molecules. The most common substance used as a desiccant compiler is silica gel which is a form of silica dioxide (SiO2). The use of desiccants in dehumidifier is used to attract moisture from the air by creating low vapor pressure areas on the surface of the material [3].

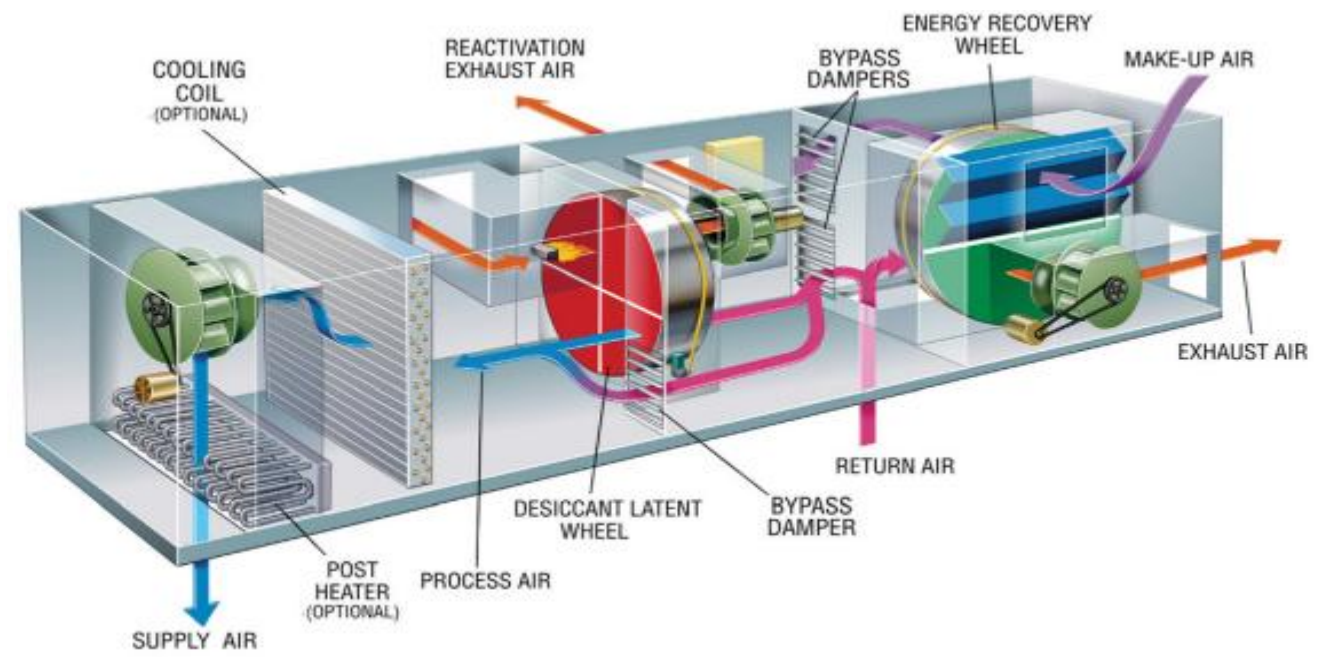

Figure. 1. Configuration wheel desiccant[3]

Calculation of exhaust heat is determined by estimating the mass of exhaust gas obtained through correction of optimation point on engine load curve and correction to ambient condition and exhaust gas pressure according to engine maker rules [4]. The economizer that to transfer of exhaust gas heating is uses to supply hetaer of reactivation energi. The power generated by exhaust gas heat can be known by the following equation:

$$
Q_{\text {exh }}=p \cdot C_{p} \cdot \Delta T \cdot V_{e x h}
$$

Where:

Qexh =The power generated by exhaust gas $(\mathrm{kW})$

$\mathrm{p}=$ Density of exhaust gas $\left(\mathrm{kg} / \mathrm{m}^{3}\right)$

$\mathrm{C}_{\mathrm{p}} \quad=$ Specific heat $(\mathrm{kJ} / \mathrm{kg} . \mathrm{K})$

$\Delta \mathrm{T} \quad=$ Temperature difference $\left({ }^{\circ} \mathrm{C}\right)$

$\mathrm{V}_{\mathrm{exh}} \quad=$ Exhaust gas flow capacity $\left(\mathrm{m}^{3} / \mathrm{s}\right)$

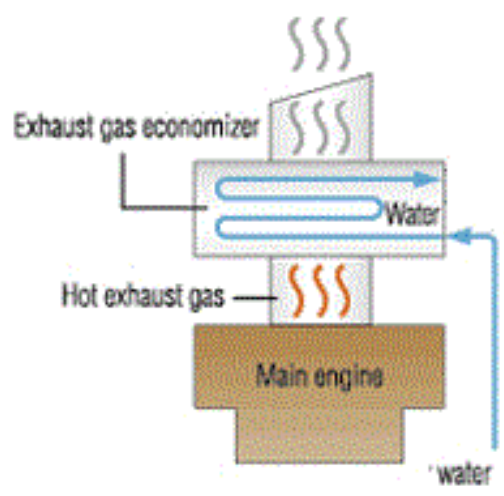

Figure. 2. Exhust Gas Economizer[5]

Calculation of heat load is performed by calculating the heat source of the ship's load space, which is the heat of solar radiation $(\emptyset \mathrm{s})$. Estimation of parameter values in determining heat load refers to ISO 7574 : Ship and Marine TechnologyAir Conditioning and Ventilation of Accomodation Spaces[6]. The solar heat burden ( $\varnothing$ total) can be calculated based on the equation:

$$
\emptyset_{s}=\Sigma A_{V} K \cdot T_{r}+\Sigma \dot{A}_{g} G_{s}
$$

In determining the design of the cooling system can be done using calculations of energy equilibrium $\mathrm{ie} Q=m_{*} \cdot \Delta T$. [4]. In the type of cooling use seawater as 
medium of cooling system. The system need to calculate flowrate the sewater is fulfill requirmnent of cooling capacity [14]. The cooling capacity that uses to decrease the temperature is result for procces dehumidification of rotary desiccant. The flowrate of sewater that uses as medium of cooling system is to select the seawater pump with the requirment of system [15-17]. The seawater pump have function to circulating supply cooling fluid.

Mass equilibrium

$$
\begin{aligned}
\text { Early }+ \text { Procces } & =\text { End } \\
m_{d a} . W_{2}+m_{w} & =m_{d a} \cdot W_{1} \\
m_{w} & =m_{d a} \cdot\left(W_{l}-W_{2}\right)(3) \\
\text { Calculation Flowrate } & \\
\text { Flowrate } & =\text { Mass flowrate/density } \\
q & =\frac{\dot{m}_{e}}{\rho}
\end{aligned}
$$

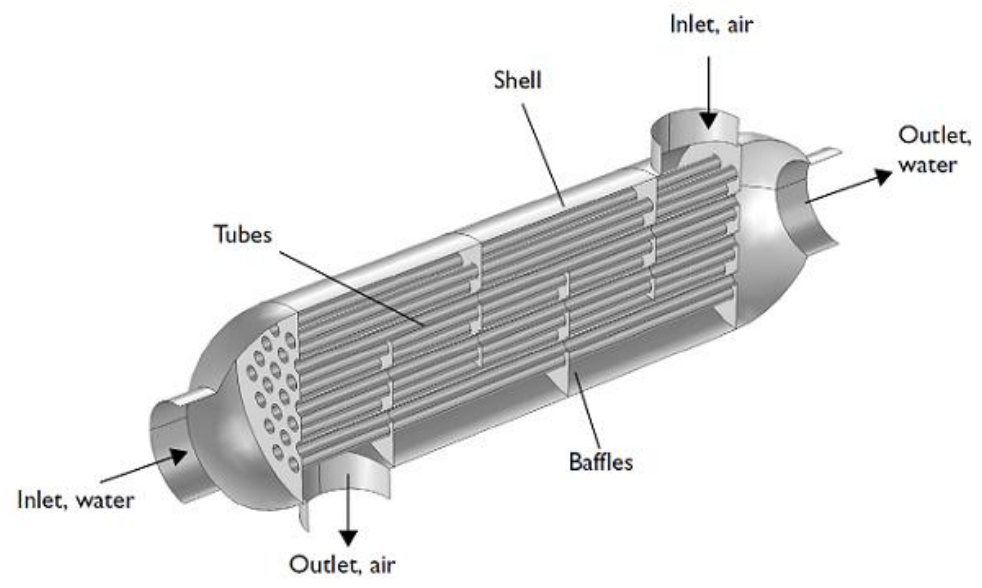

Figure. 3. Type Cooling [7]

Solar energy is energy derived from the process of converting solar heat through certain equipment into a resource in anotherenergi. Solar energy is one source of power generation other than water, steam, wind, biogas, coal, and petroleum [13].

The development of the use of solar energy reappeared in 1958. Silicon cells used to convert solar energy into resources began to be taken into calculation as a new method, since it could be used as a resource for space satellites [8].

The equation used to determine the capacity of the solar system:

$$
\mathrm{P}_{\text {solar panel }} \quad=\frac{E T}{\text { Sun inswlationi }} \times f
$$

Where :

ET =Total energy power $(\mathrm{Wh})$

$f \quad=$ Correction factor $(1,1)$

\section{METHOD}

In supporting to make this research it is needed a sequence of methods that become the framework of reference in the completion of this research. The methodology of this thesis contains steps to solve the problem in the work of this thesis. Starting from the formulation of the problem until later concludes the conclusion on the work of this thesis. The methodology used in this thesis is through the four main stages, the first is to design the dehumidification system using rotary desiccants, the second phase is to design the heating and cooling needs, the third is to design the electricity needs fulfillment system, and the last stage is to do the design condition suitability analysis.

The first step in this thesis is to determine the design schema and initial condition as a reference in determining the calculation parameters. Furthermore, it calculates the volume of vessel loading space and determines the value of air changes per hour in accordance with the recommendation of BKI, to obtain the air capacity to be supplied as well as the technical specifications of the rotor desiccant.

The next step is to design the need for reactivation air heaters for the desiccant rotor and the dehumidification air conditioning system requirements. Heating needs planning is done by calculating the required power from the heaters to be designed. Next is the calculation of the power generated by the heat from exhaust gas from the main engine. To determine the cooling system is done by calculating the cooling load from the dehumidified air desiccant dehumidifying process adjusted to the initial design temperature for cargo hold. In the cooling system can be determined the estimation of the compressive capacity that can be produced by utilizing sea water as a cooling medium.

The next step is the designing of the electrical system. The electrical system on this system uses modul photovoltaic that utilize solar energy as a source of energy. In determining the solar panel to be installed it needs to calculate the power load on the solar desiccant system. After that it is necessary to estimate the selection of equipment specification to be used in the system.

The final step is to analyze the suitability of design conditions. The analysis is conducted to determine is the design of designed to maintain the cargo hold condition 
based on the type of cargo transported. The suitability of the cargo hold condition is determined by considering the air dehumidification parameters of the dehumidification process. And its relation to the cooling ability before being supplied into the cargo hold.

\section{RESULTS AND DISCUSSION}

A. Design Desiccant System

Here is the flow diagram design of the solar desiccant system used:

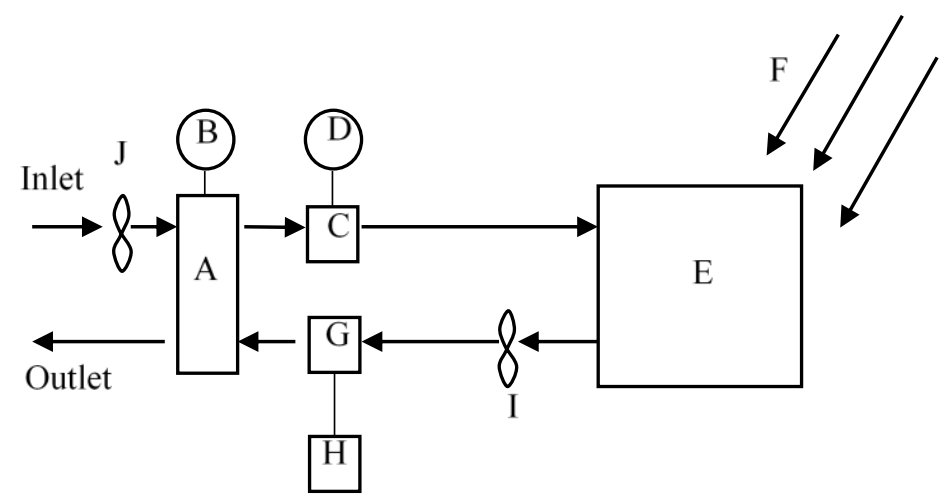

Figure. 4. Flow diagramsolar Desiccant SYSTEM

(A: Desiccant wheel; B: Electric Motro C: Cooling; D: Sea Water Pump; E: Cargo Hold; F: Solar Radiation; G: Heater ; H: Thermal Oil Pump; I: Exhaust Fan; J:Supply Fan)

\section{B. Design Condition Determination}

The outside air at $38.5^{\circ} \mathrm{C}$ with $83.1 \% \mathrm{RH}$ will be conditioned at $35^{\circ} \mathrm{C}$ with $65 \% \mathrm{RH}$. That according from the table 1 obtained which cargo handbook.From the table 1 obtained the initial design conditions of the system.

TABLE 1 .

STANDARD TEMPERATURE AND RELATIVE HUMIDITY STORAGE OF STAPLES LOAD

\begin{tabular}{llcc}
\hline \hline No. & Materials & $\begin{array}{l}\text { Temperature } \\
\text { Max }\left({ }^{\mathbf{0}} \mathbf{C}\right)\end{array}$ & RH Max (\%) \\
\hline $\mathbf{1}$ & Sugar & 43 & 65 \\
$\mathbf{2}$ & Rice & 43 & 70 \\
$\mathbf{3}$ & Flour & - & 65 \\
\hline \hline
\end{tabular}

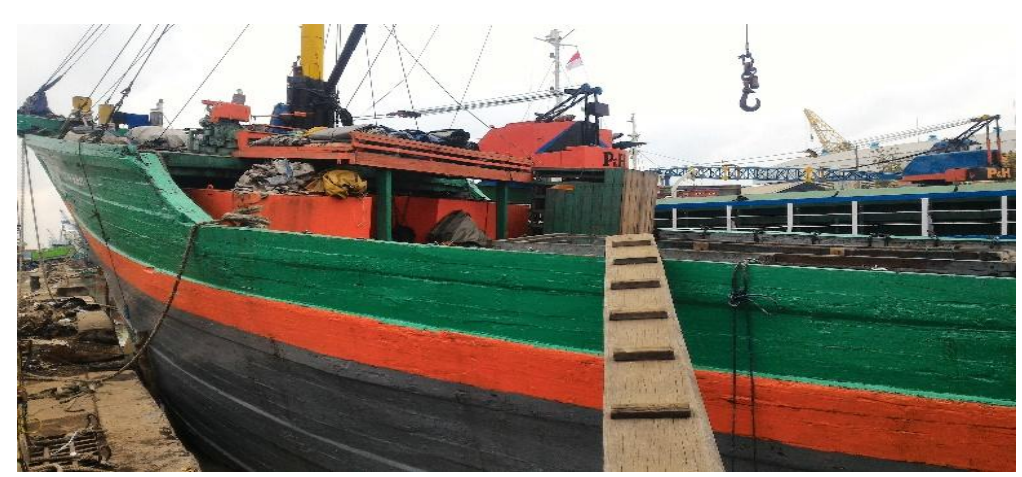

Figure. 5. KLM Pesona Bahari 


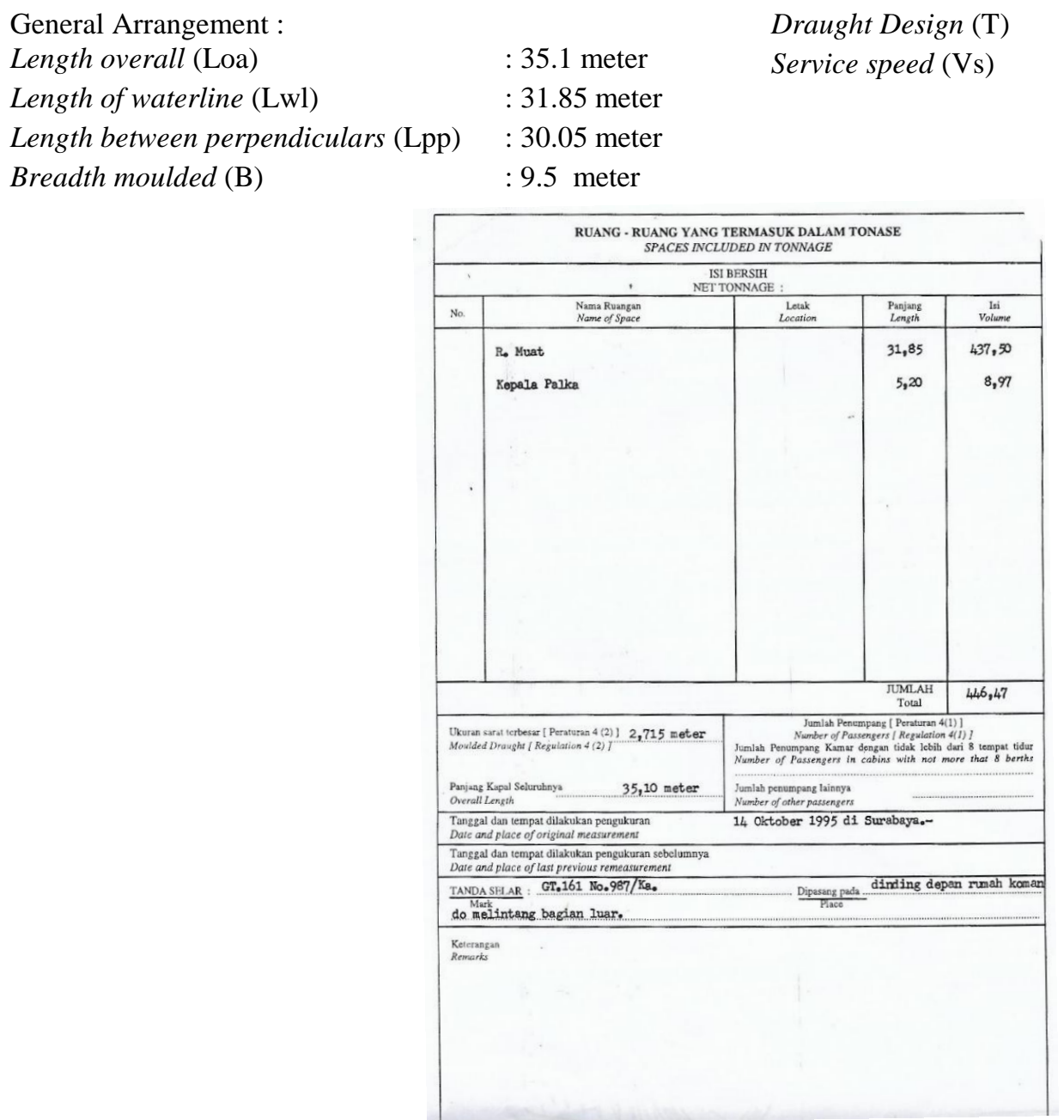

: 3.62 meter

Length overall (Loa)

: 35.1 meter

Length between perpendiculars (Lpp)
: 10.2 knot

Figure. 6. Intenational Ship Surveying Letter of KLM. Pesona Bahari

The total volume of cargo hold ship (vol.) Based on data capacity plan is $437.5 \mathrm{~m}^{3}$. While the value of air changes per hour (n) based on BKI Ventilation is 6 air changes per hour. The calculation from that obtained of requirment capacity to fulfill the system. Capacity is the air of quantity that must be in the supply into the system. So the air capacity $\left(Q_{\text {air }}\right)$ :

$$
\begin{aligned}
Q_{\text {air }} & =n x \text { vol. } \\
& =6 x 437.5 \\
& =2625 \mathrm{~m}^{3} / \mathrm{h}
\end{aligned}
$$

\section{Dehumidification Procces}

Determination of specification from rotor desiccant is done with the assisted of the Desiccant Wheel Simulation Program. The desiccant diameters are selected based on the availability of space in the accommodation space and the ability to lower the humidity ratio [16]. To selected desiccant rotor need to known quantity of air flow, temperature, reactivation of temperature and humiduty rasio. Input parameters to determine the desiccant specification are shown in Table 2.

TABLE 2

INPUTS PARAMETERS FOR THE DESICCANT PROCCES

\begin{tabular}{ll}
\hline \multicolumn{1}{c}{ Parameter } & \multicolumn{1}{c}{ Value } \\
\hline Process Air Inlet & \\
Air flow & $2625 \mathrm{~m}^{3} / \mathrm{h}$ \\
DB Temperature & $38.5^{\circ} \mathrm{C}$ \\
Humidity Ratio & 83.1 \\
Regen Air & \\
T react & $66^{\circ} \mathrm{C}$ \\
R/P Ratio & 0.333 \\
\hline \hline
\end{tabular}


The result of dehumidification process using desiccant wheel with size of $550 \mathrm{~mm} \times 200 \mathrm{~mm}$ in air temperature of $47.7^{\circ} \mathrm{C}$ with relative humidity of $46.5 \%$. It has been corresponding with the relative humidity condition of the initial design of $65 \%$. However, for the initial temperature design conditions are still too high at $43^{\circ} \mathrm{C}$.
So, we need to cooling to reduce the air temperature into the outside air temperature of $35^{\circ} \mathrm{C}$. The specification of rotor desiccant can be supply the system. The spesicification of rotor desiccant are shown in Table 3.

TABLE 3

SPECification Silicia Gel Desiccant [9]

\begin{tabular}{cccccc}
\hline \hline $\begin{array}{c}\text { Model } \\
\text { No. }\end{array}$ & $\begin{array}{c}\text { Wheel } \\
\text { diameter } \\
(\mathrm{mm})\end{array}$ & $\begin{array}{c}\text { Wheel } \\
\text { depth } \\
(\mathrm{mm})\end{array}$ & $\begin{array}{c}\text { Cassette } \\
\text { Height/Width } \\
\text { (inches) }\end{array}$ & $\begin{array}{c}\text { Cassette } \\
\text { depth } \\
\text { (inches) } \\
\text { B }\end{array}$ & $\begin{array}{c}\text { Approx. } \\
\text { total Wt. } \\
\text { (pounds) }\end{array}$ \\
\hline 550 & 550 & 200 & 35.8 & 12 & 180 \\
\hline \hline
\end{tabular}

\section{Design Heater Requirment}

Based on the result of dehumidification procces, is the requirment of temperature heater for rotary desiccantis $66^{\circ} \mathrm{C}$. The air flow for the regeneration process starts from the air of cargo hold to the desiccant wheel. Input parameters to determine the design heater of energi reactivation system shown in Table 4 .
As a fulfillment of requirment heater is used heat from main engine exhaust gas as amedia reactivation air heater with a heat transfer medium therma oil. The power generated by exhaust gas heat is obtained through estimation calculation of the mass and the exhaust gas temperature by engine exhaust gas data from your project Nissan NKC-RH10C used.To determine the temperature and mass flowrate exhaust gas of main engine shown in Table 5.

TABLE 4.

INDICATORS DESIGN HEATER

\begin{tabular}{ll}
\hline \hline \multicolumn{1}{c}{ Parameters } & \multicolumn{1}{c}{ Value } \\
\hline Outside air temperature $\left(T_{l}\right)$ & $35^{\circ} \mathrm{C}$ \\
Reactivation air temperature $\left(T_{2}\right)$ & $66^{\circ} \mathrm{C}$ \\
Average temperature & $85.5^{\circ} \mathrm{C}$ \\
Heat specific $\left(C_{p}\right)$ & $1.00636 \mathrm{~kJ} / \mathrm{kg} . \mathrm{K}$ \\
Density $(\rho)$ & $1.14152 \mathrm{~kg} / \mathrm{m}^{3}$ \\
Mass flowrate $(m)$ & $0.832 \mathrm{~kg} / \mathrm{s}$ \\
Energi heater $\left(q_{\text {heater } ~}\right)$ & $24.292 \mathrm{~kW}$ \\
\hline \hline
\end{tabular}

TABLE5. MASS Flowrate AND Temperature EXhaust Gas Main Engine [10]

\begin{tabular}{ccc}
\hline At \% Power & Flow Rate $(\mathrm{kg} / \mathrm{s})$ & Temperature $\left({ }^{\circ} \mathrm{C}\right)$ \\
\hline $100 \%$ Power & 1.55 & 370 \\
$85 \%$ Power & 1.39 & 340 \\
$75 \%$ Power & 1.2 & 350 \\
$50 \%$ Power & 0.8 & 385 \\
\hline \hline
\end{tabular}

Thus, the capacity of the exhaust gas flow( $\dot{m} E)$, the heat power of the exhaust gas is calculated by equation 1 so thatis :

$$
\begin{aligned}
Q_{\text {exh }} & =1.39 \times 1.054 \times 340 \\
& =498.12 \mathrm{~kW}
\end{aligned}
$$

Power generated by exhaust gasof $498.12 \mathrm{~kW}$ can be used to supply the heater requirement of $24,292 \mathrm{~kW}$. 
E. Calculation Cooling Capacity

Based on the dehumidification process that has been done, the air temperature after passing the desiccant wheel increased to $47.7^{\circ} \mathrm{C}$. This air temperature will be let off to $35^{\circ} \mathrm{C}$ before entering into the loading space. The first step is to find the value of cooling power needs with parameters that can be seen in Table 6 .

TABLE 6.

PARAMETERS OF DESIGN COOLING

\begin{tabular}{ll}
\hline \hline \multicolumn{1}{c}{ Parameter } & \multicolumn{1}{c}{ Value } \\
\hline Outside air temperature $\left(T_{1}\right)$ & $47.7^{\circ} \mathrm{C}$ \\
Intial air temperature $\left(T_{2}\right)$ & $35^{\circ} \mathrm{C}$ \\
Heat specific $\left(C_{p}\right)$ & $1.00735 \mathrm{~kJ} / \mathrm{kg} . \mathrm{K}$ \\
Density $(\rho)$ & $1.1051 \mathrm{~kg} / \mathrm{m}^{3}$ \\
Mass flowrate $(m)$ & $0.832 \mathrm{~kg} / \mathrm{s}$ \\
Energy cooler $\left(q_{\text {heater } ~}\right)$ & $10.306 \mathrm{~kW}$ \\
\hline \hline
\end{tabular}

From the Table 6 it was found that the cooling requirement of $10.306 \mathrm{~kW}$ will be supplied with a cooler that uses the medium of sea water as a heat transfer.

\section{F. Design Cooling System}

Cooling system design begins by calculating the flow capacity of the cooling system with the sea water medium.Then we calculate the temperature change in the cargo hold due to the heat load from the solar radiation.

$\tilde{m}_{c} C_{c} \Delta T_{c}=\dot{m}_{h} C_{h} \Delta T_{h}$

$\dot{m}_{c} \times 4001.88 \times 12.7=0.6239 \times 1007.35 \times 12.7$

$$
\tilde{m}_{c}=0.1571 \mathrm{~kg} / \mathrm{s}
$$

So the flow capacity needed to supply the water cooling from seawater is

$$
\begin{gathered}
q=\frac{\tilde{m}_{c}}{\rho} \\
q=\frac{0.151}{1022.64} \\
=0.553 \mathrm{~m}^{3} / \mathrm{h}
\end{gathered}
$$

Obtained from calculating the cooling system seawater flow rate requirements to supply the cooling system amounted to $0.553 \mathrm{~m}^{3} / \mathrm{h}$. The flow rate of seawater will be used for the selection of seawater supply pump as a coolant from the solarsystem dehumidification.

\section{G. Heat Load Calculation}

The heat load that affects the cargo hold conditions comes from the heat generated by solar radiation $(\varnothing \mathrm{s})$. In this calculation process in accordance with ISO 7574 regarding : Ship and Marine Technology - Air Conditioning and Ventilation of Accomodation Spaces. With these calculations can be observed the results of the cooling system's ability to keep the condition of the cargo hold according to the initial design of the heat load caused by solar radiation. To calculate the value of the solar radiation heat load used equation 2 .

$\emptyset_{g}=\left(133_{r} .2 \times 1.1306 \times 32\right)+(0 \times 240)$

$$
\emptyset_{g}=4816.365 \text { watt }
$$

From the above calculations obtained heat generated from solar radiation of $4.816365 \mathrm{~kW}$. This heat causes temperature changes in the cargo hold vessel to conditioned by the system. The calculation of temperature changes due to solar radiation heat can use the formula:

$Q=m_{0} C_{p} \Delta \mathrm{T}$

\section{$4.8163=0.8373 x 1.0062 x \Delta \mathrm{T}$}

$$
\begin{array}{r}
\Delta \mathrm{T}=0.5717^{\circ} \mathrm{C} \\
\mathrm{T}_{2}=35+0.5717 \\
\mathrm{~T}_{2}=35.5717^{\circ} \mathrm{C}
\end{array}
$$

From the above calculation of temperature changes due to the present of heat energy from solar radiation of $0.5717^{\circ} \mathrm{C}$. So the final temperature of the cargo hold is $35.5717^{\circ} \mathrm{C}$. With these results can be observed that the ability of existing cooling system in the solar dehumidification system is able to fulfill a requirment of the system and heat load from solar radiation..

\section{H. Electrical System Design}

In the design of solar desiccant electrical system there are several considerations that needsto be considered such as insolation of the sun in an area. For electrical system design parameters using solar panels on the system required a process of changes from solar energy to the distribution of electrical energy generated. Here is the process of solar panel distribution for theneeds of the required power load solar desiccant system. 


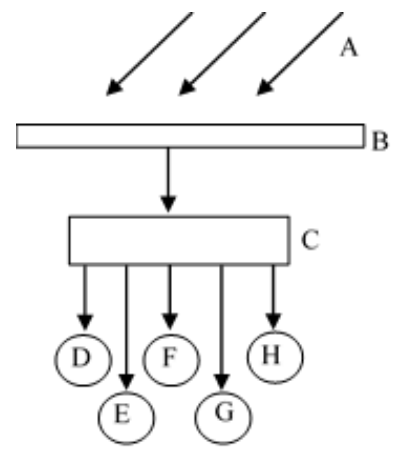

Figure. 7. Scheme of Electrical Energy Distribution of Solar Panels

(A: Solar Radiation; B: Photovoltaic; C:Battery; D: Electric Motor; E: Exhaust Fan; F: Supply Fan; G: Thermal Oil Pump; H: Sea Water Pump)

From the above scheme can be determined needs of the power load required by the system by looking for specifications of each equipment required for each system. Specification of equipment used can be seen in Table7.

TABLE 7.

SPECIFICATIONS OF DESICCANT SOLAR SYSTEM EQUIPMENT

\begin{tabular}{lllll}
\hline \hline No. & \multicolumn{1}{c}{ Equipment } & $\begin{array}{l}\text { Power } \\
(\text { Watt })\end{array}$ & $\begin{array}{c}\text { Time } \\
(\mathrm{Jam})\end{array}$ & $\begin{array}{c}\text { Energy } \\
(\mathrm{Wh})\end{array}$ \\
\hline 1 & Electric Motor & 83 & 24 & 1992 \\
2 & Exhaust Fan & 342 & 24 & 8208 \\
3 & Supply Fan & 342 & 24 & 8208 \\
4 & Thermal Oil Pump & 300 & 24 & 7200 \\
5 & Sea Water Pump & 370 & 24 & 8880 \\
\hline \hline
\end{tabular}

From the Table 7 it is found that the total energy required by the system is $34488 \mathrm{Wh}$..

$$
\begin{aligned}
& \mathrm{ET}=\mathrm{EA}+(15 \% \mathrm{EA}) \quad \text { losses equipment } 15 \% \\
& \mathrm{ET}=34488+(15 \% \times 34488) \\
& \mathrm{ET}=39661.2 \mathrm{Wh}
\end{aligned}
$$

Energy requirements of the calculated system, which amounted to $39661.2 \mathrm{WH}$. The lowest monthly solar insolation was in January 2015 ie 3.91. For the adjustment factor the installation is 1.1.

$$
\begin{aligned}
\text { Power module capacity } & =\frac{39661,2}{3,91} x 1_{s} 1 \\
& =11157,88 \mathrm{wp}
\end{aligned}
$$

The photovoltaic module to be used has the following specifications:
Power capacity
Maximum current
$=345 \mathrm{WP}$
Maximum voltage
$=6.02$ Ampere
$=57.3 \mathrm{Volt}$
$=1.6 \times 1.05 \mathrm{~m}$
Dimensions

Because the solar power module capacity is $11157.88 \mathrm{Wp}$ and the power capacity of 1 unit of photovoltaic $345 \mathrm{WP}$ can be made equation:

$$
\Sigma \mathrm{m}=\frac{\text { power capacity }}{\text { power capacity/unit }}
$$

$$
=33 \text { unit. }
$$

Of the total solar module of 33 units then the required area required for $55.44 \mathrm{~m}^{2}$. While the extent of existing solar module placement on the vessel of $9.5 \times 8.5=80.75$ $\mathrm{m}^{2}$, then the extent that still exists.

\section{CONCLUSION}

From the calculation and analysis of data that has been done to design air ventilation system using solar desiccant, it can be concluded that:

1. From result of calculation analysis to dehumidification process of cargo hold volume equal to $437.5 \mathrm{~m}^{3}$ at 6 air changes / hour got desiccant wheel specification which best compatible with diameter $550 \mathrm{~mm}$ and thickness $200 \mathrm{~mm}$.

2. The ratio of outside air humidity at $38,5^{\circ} \mathrm{C}$ temperature of $83.1 \%$ can be decreased to $46.5 \%$ at $35.6^{\circ} \mathrm{Ca}$ cargo hold temperature after passing the desiccant wheel.

3. To requirment desiccant heating requirement of $24.292 \mathrm{~kW}$, heat exhaust gas from main engine with temperature of $350^{\circ} \mathrm{C}$ and produce power equal to $498.12 \mathrm{~kW}$. Therefore, it is requirfor the economizer to transfer heat energy from the exhaust gas meter. With the requirement of 24.292 
heater energy, economizer with thermal oil fluid as heat transfer medium. The required cross-sectional area is $0.1828 \mathrm{~m}^{2}$. While the use of sea water as a cooling medium can reduce the temperature of $12.7^{\circ} \mathrm{C}$ with the flow of sea water flow of 0.553 $\mathrm{m}^{3} / \mathrm{h}$.

4. To fulfill the electric power requirement of solar desiccant system $34.488 \mathrm{Wh}$ with 1 day storage capacity obtained amount of module power requirement equal to $11.157,88 \mathrm{wp}$. From the module's power capacity requirement, the solar module is required for 33 units with a capacity of 345 wp each.

\section{REFERENCES}

[1] Paraya, Lutfi, "Analisa Ventilasi Udara Pada Ruang Muat Kapal General Cargo yang Telah Dikonversi Menjadi Livestock Vessel" Jurnal Ilmiah Teknik Sistem Perkapalan ITS, 2010.

[2] Shafar Fauzi, Hadist, "Desain Alternatif Sistem Ventilasi Udarapada Ruang Muat Kapal PengangkutTernak dengan Menggunakan TwoWheelDesiccant”, Jurnal Teknik Sistem Perkapalan ITS, 2016.

[3] Harriman, Lewis G., "The Dehumidification Handbook Second Edition", Munters Corporation, Amesbury USA, 2002.

[4] Holman, JP, "Heat Transfer Tenth Edition", Raghothaman Srinivasan, New York USA, 2010

[5] Use of Waste Heat Energi of Exhaust Gas. Url : https://www.kline.co.jp/en/csr/environment/climatechange.html Diakses pada : 16 Juli 2017

[6] Intenational Standart, "ISO 7574 : Ship and Marine Technology - Air Conditioning and Ventilation of Accomodation Spaces", ISO 2002.

[7] Hankins, Mark. 1991. Small Solar Electric Systems for Africa. Motif Creative Arts, Ltd,Kenya. Scientific Publications "The role of energy in supporting sustainable development", Directorate of BPPT energy technologies, in May 1995, Jakarta.

[8] Palwaguna. Hasan, Tugas Makalah 1 OPK - Desain Heat Exchanger, Bandung, 2016,

[9] Inc. Rotorsource, 2011, "Desiccant Dehumidification Technical Information",Baton Rouge LA, 2011

[10] Nissan, "NKC-RH10C Nissan Project Guide", 2001.

[11] H. Prastowo, A. Santoso, and A. Arya, "Analysis and Optimation Hydrofoil Supported Catamaran (HYSUCAT) Size 25 Meter based on CFD Method,"International Journal of Marine Engineering Innovation and Research., vol. 1, no. 1, Dec. 2016.

[12] A. Baheramsyah, B. Cahyono, and F. S. Aruan, "Slurry Ice as a Cooling System on 30 GT Fishing Vessel," International Journal of Marine Engineering Innovation and Research., vol. 1, no. 3, Jun. 2017.

[13] M. Mukhtasor, T. B. Musriyadi, I. S. Arief, and A. W. C. Saputra, "Horizontal Pendulum Performance Analysis with Multilevel Model Plate on Ocean Wave Electric Power Plant (PLTGL)," International Journal of Marine Engineering Innovation and Research., vol. 1, no. 2, Mar. 2017.

[14] [A. Amiadji, E. Djatmiko, and Y. N. Prasetyo, "Efficiency Analysis of Additions of Ice Flake in Cargo Hold Cooling System of Fishing Vessel," International Journal of Marine Engineering Innovation and Research., vol. 1, no. 3, Jun. 2017.

[15] [A. Z. M. Fathallah, W. Busse, and F. R. Clausthaldi, "Fluid Flow Analysis of Jacket Cooling System for Marine Diesel Engine $93 \mathrm{Kw}$," International Journal of Marine Engineering Innovation and Research., vol. 1, no. 2, Mar. 2017.
[16] T. Pitana, S. Gurning, and F. Fikri, "Modelling of LPG Ship Distribution in Western of Indonesia using Discrete Simulation Method," International Journal of Marine Engineering Innovation and Research., vol. 1, no. 3, Jun. 2017.

[17] Prastowo, H., Widodo, D.P. and Rohmawati, W., 2017. Technical Analysis Ballast Water Treatment By Using Economizer Utilizing Main Engines Exhaust Heat To Comply With International Ship Ballast Water Management At MV. Leader Win. International Journal of Marine Engineering Innovation and Research, 1(2).

[18] Semin, Al.Baheramsyah, Amiadji and A.R. Ismail. (2011). Effect of Dry Ice Application in Fish Hold of Fishing Boat on the Fish Quality and Fisherman Income. American Journal of Applied Sciences 8 (12): 1263-1267. 